FOOD, WORK AND ORGANIZATION SPECIAL ISSUE

MANNA FROM HEAVEN: THE EXUBERANCE OF FOOD AS A TOPIC FOR RESEARCH IN MANAGEMENT AND ORGANIZATION ${ }^{1}$

\author{
MIGUEL PINA E CUNHA \\ Faculdade de Economia \\ Universidade Nova de Lisboa \\ Rua Marquês de Fronteira, 20 \\ 1099-038 Lisboa; Portugal \\ email: mpc@fe.unl.pt \\ Tel: 351-212 822725 \\ Fax: 351-213 873973
}

\author{
CARLOS CABRAL-CARDOSO \\ School of Economics and Management \\ University of Minho \\ Gualtar, 4710-057 Braga; Portugal \\ Email: ccabral@eeg.uminho.pt \\ Tel: 351-253-604553 \\ Fax: 351-253-676375 \\ STEWART R. CLEGG ${ }^{2}$ \\ School of Management \\ University of Technology, Sydney \\ PO Box 123 \\ Broadway NSW 2007 Australia \\ and \\ Aston Business School \\ Work Organizational Psychology Group \\ Aston University \\ Aston Triangle \\ Birmingham B4 7ET UK \\ Email: s.clegg@aston.ac.uk
}

Tel: 441212044994

\footnotetext{
${ }^{1}$ Insightful comments of guest editors and three anonymous referees were extremely useful. Miguel Cunha acknowledges support from Instituto Nova Forum.

${ }^{2}$ Stewart Clegg is also a Visiting Professor and International Fellow in Discourse and Management Theory, Centre of Comparative Social Studies, Vrije Universiteit of Amsterdam, Netherlands; Visiting Professor of Organizational Change Management, Maastricht University Faculty of Business; Visiting Professor EM Lyon Business School Doctoral Program, France, and Visiting Professor at Copenhagen Business School.
} 


\title{
MANNA FROM HEAVEN: THE EXUBERANCE OF FOOD AS A TOPIC FOR RESEARCH IN MANAGEMENT AND ORGANIZATION
}

\begin{abstract}
Organizations have, in the past, often been discussed as if they were Cartesian mentalities, planning agendas, learning from doing, processing information, reducing equivocality, mimicking and copying, floating disembodiedly apart from the actors who work in these organizations. We are offered representations of organizations as organically grounded metaphors that minimize the biological facticity of employees: namely, their need for food. While the inputs to organizations conceived as if they were quasi-systems are well explored, and the emotional and 'irrational' side of organizations is increasingly discussed, the necessity of inputs to the biological systems that staff them is not. Nonetheless, despite the lack of explicit scholarly attention to food at work, its importance guarantees its hidden presence in the organizational literature, often in the context of more "serious" themes. We identify four approaches to the relationship between food, work and organization. For dessert, we propose a research menu that aims to uncover several possibilities for making the role of food in organizational life more explicit.
\end{abstract}

Keywords: food, eating, work, organization, body 


\section{INTRODUCTION}

Contributors to Rafaeli and Pratt's (2006) edited volume have illustrated the impact of a number of organizational artifacts, from attire to the business card. The organization is a veritable treasure trove of the ways in which we present our selves in everyday life (Goffman 1956). A neglected organizational prop, artefact and impression management device is food. In organizations we are constantly positioning ourselves but even the slimmest figure cutting a bespoke dash, presenting haute couture - or prêt-a-porter - to the general gaze, needs to eat, whether in canteens and cafeterias, at business lunches, in brown bag seminars, at Christmas dinners, company picnics or Friday evening beer bashes. Food serves not only to feed but also to communicate, to commemorate, to conserve tradition, to mark the passage of time, to express abundance, to build trust and proximity, to create intimacy, to show appreciation, and to retain employees. Eating habits frame national cultures: the Scandinavian open sandwich lunch serves a purpose different from the long midday lunch of Latin countries, where the main meal of the day is eaten, ideally with a small siesta following to aid digestion.

While some taste for fashion is optional as we clothe ourselves according to various dress codes, such as the dress for success ethic of the sharp suit and the elegant blouse serving as props for organizational presentations, a taste for food is essential to all human existence and thus for the life of organizations. It has, however, been underrepresented per se as a research topic in the field of organizations although it has been explored in a number of ways, mostly indirectly. The "oblique" presence of food in current research may thus be complemented with research directed to the role of food itself. In this paper we uncover the presence of food in organizational research. We do it in three ways. First, by connecting texts that are dispersed and that pertain to different 
literatures, we suggest that food is a relevant organizational topic. Second, by organizing a frame for the analysis of the topic, we propose a conceptually-based approach to the theme. The roadmap so provided synthesizes previous work on the topic. Third, by exposing unanswered questions we indicate ways for future research.

We therefore suggest that it is possible to better understand organizations and the process of organizing by studying the way organizations deal with food. The reasons for this are diverse. First, in making a relationship between food and organization people often occupy an in-between space, at the boundaries of the formal and the informal organization, the inner and the outer space. Second, the scientific focus on the grand side of organizational life (the serious and scientific terrain of strategies, mergers and acquisitions, CEO succession and so forth) as formal organization coexists with a mundane side, a world barely attended to in management science, a world of biological needs and wants and social rituals associated with the satisfaction of these, around whose ceremonies and rituals a great deal of organization life revolves - both formal and informal.. Third, in the spirit of this special issue, it may be advantageous to study food per se, as a research topic rather than addressing it in an oblique way, en passant, when studying other topics.

We aim to contribute to the literature on the topic of food via the presentation of a preliminary typology of food and organization, and the derivation of a number of research topics from this typology. The result is a more complete and integrated roadmap for furthering research on food and organization, and positioning food into the larger context of organization theory. Before moving to the typology, we start our discussion with an analysis of organizations as biological systems, literally speaking, 
and then focus on how the management and organization literature approached this essential facet of humanity.

\section{BODY, FOOD, AND ORGANIZATION}

There is a revealing dichotomy in the relationship between the body and organizations: people are bodily beings, tempted by the senses and eager to enjoy physical experiences, hence the significance given to marketing, the consumer experience and other ways of capturing the role of physical/physiological experiences in consumption. As consumers, they have subtle and not necessarily rational preferences that are minutely analysed; these give rise to a whole discourse of marketing and push selling designed to excite irrational impulses. Research on consumer behaviour is replete with studies on the way organizations try to influence people’s behaviour by manipulating their physical senses, i.e., their bodies. The aroma of coffee injected into the freezedried tin of instant coffee evokes the real thing - at least the first time the foil is perforated. Almost all up-market real estate agents today know the importance of the aromas of freshly baked or bought bread, fresh flowers, and fresh coffee, supporting the tasteful baroque music or Latin jazz and fashionable lifestyle magazines and novels, as a part of the armoury of props when the house is open for inspection during a sales campaign.

A noticeable quality of food is its olfactory seduction. The interest in the influence of consumer behaviour ranges from the physical to the conceptual. One example of the physical interest is Guégen and Petr’s study (2006), which showed how lavender (but not lemon) aromas increase the amount of purchasing in a restaurant. The consumer behaviour literature is rich in advice on the relation between the sense data of taste and 
smell and organizational outcomes. Ordinarily, olfaction is regarded as an independent causal attractor, although a reverse relation between taste and smell as sense data and organization success can be invoked. As food is associated with entertainment themes (e.g., Hard Rock Cafe, Planet Hollywood, and Fashion Café) in “eatertainment” (Ritzer, 1999), then: the brand is projected on to the food such that in consuming the food and drink on offer you partake of the mystique of the brand. It is the brand that seduces rather than the sense data. Perhaps after enough visits the sense data will kick in as a conditioned response?

If consumer marketing is a valuable source of data on the relation between bodies, their sense data, and organization, it is the science of ergonomics, whose origins date from Taylorism as a systematic process of rendering bodies docile (Clegg et al., 2006), which is the chief locus for the study of the body at work and in organizations for the management sciences (Salvendy, 1997). A central goal of Taylor's (1911) effort was to limit social antagonism and curb unruly bodies through a scientific, mutually-beneficial system of work organization, rest and meal breaks - and the latter were to be rigorously separated from work time. Subsequently, Ford’s Sociological Department sought to create workers whose bodies were well-adjusted to the new regime of work on the moving production line: sober, disciplined, well-rested, preferably mortgaged and married, and properly fed. As discussed by Harquail (2006), employees are still often managed as physical artifacts in/of the organization. The human relations movement of the 1930s was often associated in personnel practice with the provision of canteens as a major piece of corporate welfare infrastructure. 
Outside of the consumer behaviour, ergonomics and human relations literature, discussion of the stubborn, irreducibly embodied aspects of people is often excluded through the ways that organizations are frequently systematized. Organizations are often presented as cold spaces of reason and cognition, at their best as superordinate brains (Beer, 1981) or at their worst as psychological prisons (Morgan, 1986). The organization, especially as it is represented in induction texts - the introductory textbooks - suppresses the body and the embodied nature of experience. Organization becomes represented as the space of the brain and of self-control. The recent "discovery" of the role of emotion is a demonstration of how the theory of organization and management neglected the role of physicality and its importance in a biological world (Fineman 1996). Research has shown that leaders lead not only with brains but also with bodies, (Sinclair, 2006). While there is a huge organizational literature on the environment, latterly in 'natural' terms, the most direct and unavoidable natural environment for each organizational member is his/her body and how it interacts with the physical environment surrounding it, with a central form of interaction being its replenishment.

Recently, the body has reappeared in the organizational literature and, while books have been edited on the body (Hassard, Holliday and Willmott, 2000), workplace romance, sexuality (Hearn, Sheppard, Tancred-Sheriff and Burrell, 1989), and the necessity of policies to limit sexual harassment, they seem not to have addressed the embodied need for food and its consumption. While the gendering of organization theory is, of course, well developed, with journals devoted to the topic (Gender, Work and Organization, Women in Management Review), we have yet to find articles, using Google Scholar, on topics such as “organizations and obesity”, “organizations and bulimia”, “organizations 
and anorexia”, “organizations and slimming', or “organizations and diet”. Interestingly, we composed this list because in the popular press the bodily topics that attract most attention are those where bodies deviate from organizational prescriptions and ostensively show their physicality, i.e., when they become transgressor bodies.

In summary, the body has an extensive, albeit discrete, presence in the organizational literature (Shilling, 1993). The presence of the body is manifested in gender stereotypes (Schein et al., 1996), dress codes (Rafaeli et al., 1997), ergonomic approaches and time and motion studies (Adler, 1993), disappearing bodies as reflected, for instance, in business process re-engineering (Hammer and Champy, 1993), bodily presence such as in open or closed space design (Hofbauer, 2000; Clegg and Kornberger, 2006), physical presence, with psychological escape being possible through various everyday 'escape attempts’ (Cohen and Taylor, 1976), and so forth. In a sense, organization theory may be viewed as the study of bodies at work. But bodies need feeding - a fact which has attracted considerably less scholarly attention than all the above topics. If the body has a marginal but discernible presence in organizational studies, food has an even more marginal space in the body and organization literature.

\section{THEORIZING FOOD AND ORGANIZATIONS}

In part, the relative marginalization of food as a topic for organization theory may have to do with pre-existing academic divisions of labour: the prior division of the field of sociology into the sociology of organizations, industrial sociology and the sociology of agriculture as specialist subfields and the development of an industrial economics and an agricultural economics in the economics literature tended to consign matters of agrarian production to a specialist field, far away from the core concerns of the parent 
disciplines application to industry, economics and organizations. As organization theory emerged from these - and other predecessors - as a hybrid then the already implicit and systematic emphases and ellipses were carried into its intellectual productions. Yet, food has long played an important role in economic and historical analysis.

The transition from feudalism to capitalism was spurred in part, according to Perry Anderson (1974), because of food. Feeding the existing population increasingly came up against technological limits to the available means of agricultural production. Heavy clay soils, existing drainage technologies and methods of ploughing meant that the available land was increasingly exhausted and not easily extended. An increasing population could neither be fed adequately nor could an escalating need for surpluses to wage wars be maintained on the part of feudal warlords who expropriated surplus produce. For this reason the plague virus, carried by rats, was able to wreak havoc on a weakened European population, making the remaining peasantry stronger both in political and calorific terms, hastening their resistance to the nobles, and flight to emerging free towns in the interstices of feudalism The centrality of food as biological necessity - as well its complex role in social relations - is clear from this important historical example. We shall consider some of these social relations next.

From the sixteenth century, food production was the basis for the most sustained forcible migration and exploitation of non-European lands that the world had seen, with the growth of the slave trade and a plantation economy in the Americas. From differently specialized roles in the world economy that developed from this trade plantation economies in the Americas and manufactures on the Atlantic seaboard - there emerged in the 'long sixteenth century' the modern world system, according to 
Wallerstein (1974). During much of the early half of the nineteenth century the most central element in political debates in Britain concerned food and what to do with the surplus agricultural population that had developed as a result of the enclosure movement, from the seventeenth century onwards, a debate which gave rise not only to the Poor Laws but also the workhouse. The latter was Bentham's solution to the problem consisting of an organization for training the surplus categories of population in the disciplines of work and turning idle hands to active duty in the labour force. Even into the twentieth century, the system design of how food was to be produced remained central to major organizational issues. The Stalinist collectivization of kulak agriculture from 1927 cost many millions of lives while seeing agriculture in the Soviet Union transformed on the basis of a theory of organization - albeit one that was fatally flawed (Conquest 1986). Similarly, with the Great Leap Forward of Mao in 1950s China, when millions of peasants switched from agriculture to cottage industry agriculture, with disastrous results both for the quality of manufactures and the quantity of food (Fairbank 1992). Finally, in more recent times, we have seen the organization of the ‘Green Revolution’ in the 1960s, premised on the organizational success of the chemical industry in developing fertilizers and pesticides and the swing against the agro-chemical industrial farming complex that developed in the movement of Green politics and the demand for sustainable agriculture, irrigation, and local - rather than global - food markets. The system design of how food's materiality should be delivered has been an essential element of economic and social history.

Of course, the organization of food is not merely a matter of its production; it also touches on its consumption, as we have seen from the earlier discussion. For Marx (1976) the reproduction costs of a British labourer, included calculations of the cost of 
beer while for peasants in sunnier climes the relevant calculation might include wine. If drink is a central issue so is bread: consider the debates over the Corn Laws that, with the politics of the Poor Laws, were at the centre of early nineteenth century domestic political debates in Britain. It was in the interests of the employers of a rapidly growing industrial proletariat to employ them at the lowest wages, relatively, that they could. The wage rate was closely related to the reproduction costs of labour; in turn, these were highly dependent on the price of staples, especially the price of bread. Hence, for Northern industrialists, arraigned against old style Tories and the landowning class, Free Trade in corn was a central political interest. Free trade lowered the costs of social reproduction of the proletarians by making bread - the staple food in their diet cheaper. Hence, the industrialists were for Free Trade while the landowning aristocracy whose estates produced the national crop were not: cheaper imports lowered their profits by undercutting what they might obtain in a rigged market. Food may be a biological necessity but it is also a central element in social reproduction.

All organic life requires sustenance. Morgan (1986) argues that organization theory has developed through both analogy and metaphor, with the idea of the organization deriving from the root metaphor of 'organics' being one of the most pervasive metaphors. The biological nature of organizations has been explored in the organizational literature, often at macro and abstract levels, in the idea of organizations as open systems (Katz and Kahn, 1978) or the population ecology model of organizations (Hannan and Freeman, 1989). However, this organicism has rarely embraced food. Where food has entered organizational discussion metaphorically it has been in terms of metaphors derived from food production. The hastily bought and rapidly consumed meal from McDonald's is a metaphor of our time that has become a 
systematic critique symbolizing a whole mode of production (Ritzer 2002) that is oriented to rationalization through standardization and consumption as an end in itself, rather than for the aesthetic pleasure that it brings.

In this paper, we organize the relationship between food and organization around two conceptual axes. The first axis connects the materiality of food and its social construction. The material dimension refers to the satisfaction of human needs - it corresponds to the functional side of food; we may represent this as eating to live. The social constructional or symbolic dimension goes beyond the functional dimension. It represents food as part of a wider whole. As Morgan, Frost and Pondy (1983) discussed, one attribute of symbols is their capacity for "putting together”. We will connect food with organization, putting food together with organizing, a process that has received a modest amount of interest. The second axis connects producing food and consuming food. Production and consumption are necessarily interconnected; their interconnection produces an important dimension in the field of food and gastronomy, given the fact that this industry is rooted on intellectual discourses linked to these primary acts (see Durand et al., 2007); we may represent this as different discourses on ways of living to eat.

When the two axes are combined, four perspectives on food and organization emerge: food as biological necessity, food's role in social reproduction, the system designs associated with food, and the metaphorical role that the ways that food is produced play as a source of critique and metaphor for organization studies. Table 1 depicts this typology and gives the reader a first account of the rest of the paper. As the typology suggests food may be thought of a "total social phenomenon", an activity so pervasive 
in society that directly or indirectly it connects with every type of social phenomenon and institution, as noted by Ferguson (1998). For this reason food could be a rich and varied field of research in organization studies. Before proceeding with the typology, we note that while the theoretical discussion that it introduces provides clarity it also draws artificial boundaries. To advance only an obvious example, meals may be a matter of biological necessity as well as playing a role in social reproduction; however, we do not doubt that some meals do more for social reproduction than others while others are less satisfying socially but nonetheless provide sustenance for the biological organisms of the people eating them.

Table 1 about here

\section{FOOD AS BIOLOGICAL NECCESSITY}

Food is a prerequisite of life; hence, its relevance for humans and consequently for the understanding of behavior in organizations. Its space in organizational texts, however, is limited: food is something that most people, except the most desperately poor, tend to take for granted. Consequently, organizational interest moves rapidly up the need hierarchy, reducing food to a "lower” priority. Because higher needs tend to be perceived as more important than lower ones, the role of food in business and organization has not been subject to a significant amount of interest despite the fact that food and drink can be treated as significant aspects of the organizational landscape. 
The problem of obesity is an example. The way that organizations structure the satisfaction of the biological need to eat will have an impact on the eating habits of their members and their modes of consumption. The type of meals, beverages and snacks available in organizations are not an insignificant issue. They facilitate habits and lifestyles that may have an impact in the organizational functioning. Nowhere is this more evident than in the debates about school lunches and their calorific content, which has been a staple of the British newspapers in recent years, since the 'celebrity chef', Jamie Oliver, took it upon himself to reform the culinary habits of the countries' schools (see http://www.jamieoliver.com/schooldinners for a well documented account of the movement). Schools are especially important arenas for culinary contestation, considering that childhood eating habits can often be carried through to adulthood and from school to work organizations. For example, employee obesity has been associated with absenteeism (Berry et al., 2006). Hence, it is hardly surprising that the disciplining of food has become so closely associated with the disciplining of healthy bodies in the discourses surrounding the organization of food and education.

Good food has been associated with good business. As observed by an Amgen employee, responding to the Financial Times survey on the best European workplaces, “We have fruit, juices, coffee and tea, whenever we like” (Financial Times, 2006: 5). Good organizations, then, may be replete with abundant and attractive food. The connection has been made by companies such as Google, which hired former Grateful Dead chef, Charlie Ayers, to tantalize the tastes of Googlers with his fine food. Food has also been associated with intrinsic motivation, with the chef being viewed as the motivated professional par excellence (Balazs, 2002), as an entrepreneur and creative artist wrapped up in the persona of a shrewd and successful business person. 
Food provides information about the organization. One of the authors remembers working with a company whose members complained that top management devalued the organization's people. When invited to provide some evidence of this, the first answer was that the quality of food in the canteen was worse than it used to be. In this sense, food may be used to understand an organization's culture: companies are what they give to their employees to eat. Another company we worked with was a once successful dotcom fallen on leaner times; as the times got tougher the lavish BBQs and parties disappeared; eventually the milk and biscuits disappeared, then people had to bring their own coffee. As one respondent remarked, you could see the whole story of the organization's decline into eventual bankruptcy through its changing relation to foodstuffs. That is why food is often present in the description of the best companies characterized not only by their comparatively higher levels of effectiveness (Filbeck and Preece, 2003) but also by other more mundane features, including good food.

\section{FOOD AND SOCIAL REPRODUCTION}

When people have a meal together, they are in fact fulfilling different needs: (a) food helps them meet basic physical needs; (b) food gives them the opportunity for interaction and for information exchange; and (c) the quality of the food they eat functions as a symbol of status, care, respect, pleasure etc. In this section we explore these dimensions of "social food" through its role in social reproduction: food as an opportunity for social interaction, meals as liminal spaces, and food as the expression of status. 
Food plays a number of roles in organizational life. The biological need for food and refreshment becomes an occasion for interaction. Both inside and outside the organization, food can be consumed in work time or off work time (e.g., the Pizza delivered to the lab on a weekend to feed a working team of grad students). The water cooler is well-recognized as a site of organizational gossip. As observed by Fayard and Weeks (2007), the water cooler is an important spot in the ecology of informal interactions. The water cooler, as a figure of speech, is a space where people feel natural and comfortable. It can be a real water cooler, but also its substitute, for example a coffee machine or a drinks dispenser. Canteens are not just functional eating places. Food presents an opportunity for interaction, for building confidence, for sharing information and spreading gossip as well as expressing status orders.

Another glimpse of the importance of food as facilitating organizational interaction is offered by Pitsis et al.'s (2003) research on the preparation of the Sydney Olympiad. Many community meetings were associated with what was a major infrastructural construction project. These were places in which strange conversations emerged, conversations where agendas were often unclear, processes highly emergent, and outcomes unknown. In these meetings, which were often informal barbecues, community members were invited to surface anxieties and make suggestions in relation to the project (of which they had little knowledge). What they proposed was often a surprise, in routine terms, and could not have been scripted by the project members. Sometimes organizations have to provide spaces outside of their routines where improvisation can occur, such as barbecues.

Food can also work as a fine empirical setting for studying interactions in the zone of liminality (Cunha and Cabral-Cardoso, 2006), providing an "extreme case” in which the 
phenomenon of interest is "transparently observable" (Eisenhardt 1989: p.537). The business lunch can be viewed as a liminal space, with the rules of etiquette of business lunching differing from country to country. Business lunches are occasions where participants are simultaneously performing their roles and yet are partially outside these roles, often meeting in a different, neutral space of the restaurant, where the usual organizational props with which their performances are organizationally framed are absent. Different props and mastery of different details are required: skill with a wine list, the ability to eat, drink, talk and not be disagreeable in ones manners while doing so. Whitley et al. (1981) noted the importance of the social capital acquired from traditional family wealth in smoothing interactions in specific liminal spheres for elite business school students. The ski lodge, the Mediterranean yacht, and the country chateau provided exquisite framing devices for moments of gastronomic consumption, moments which effortlessly frame opportunities for doing business.

It is not merely elites that dine and do business simultaneously. For sales representatives lunch, or dinner, as a liminal space between formal organization(s), theirs and their clients, exists somewhere between what is proper and improper, even what is legal and illegal, as reflected in the quote that follows:

\footnotetext{
Every weekday, some 38,000 Pfizer Inc. sales reps fan out around the globe. Armed with briefcases full of free drug samples, reams of clinical data, and lavish expense accounts for wining and dining their quarry, the reps infiltrate doctors' offices and hospitals. Their goal: to persuade medical professionals the world over to make Pfizer drugs the treatment of choice for their patients’ aches and pains (Barrett, 2005: 51).
} 
Other possibilities for articulating food, organization and liminality may be further explored, such as virtual working from cafés, via Wi-Fi (Conlin, 2006). The substitution of the cubicle by the coffee-house may suggest a number of interesting research possibilities: Why do employees work in coffee-houses? When do they prefer to do so? What are the advantages of working from the café and what are the disadvantages? What makes a coffee-house a good substitute for the office? Does the wireless Starbucks represent a return to the original function of the coffee-house as a place of trade, as Samuel Pepys and his contemporaries used them in the $17^{\text {th }}$ century?

\footnotetext{
The London coffee-houses provided a gathering place where, for a penny admission charge, any man who was reasonably dressed could smoke his long, clay pipe, sip a dish of coffee, read the newsletters of the day, or enter into conversation with other patrons. At the period when journalism was in its infancy and the postal system was unorganised and irregular, the coffeehouse provided a centre of communication for news and information. Runners were sent round to the coffee-house to report major events of the day, such as victory in battle or political upheaval, and the newsletters and gazettes of the day were distributed chiefly in the coffeehouse. Most of the establishments functioned as reading rooms, for the cost of newspapers and pamphlets was included in the admission charge. In addition, bulletins announcing sales, sailings, and auctions covered the walls of the establishments, providing valuable information to the businessman who conducted much of his business from a table at his favourite coffeehouse (Pelzer and Pelzer 1982: 40).
}

The bars and restaurants surrounding corporate headquarters are potential liminal spaces providing rich environments in which to diagnose organizational climate and worker morale. The conversations at Miller's Bar, a mile west of Ford's headquarters in Dearborn, Michigan, at the heart of "Ford Country" provide a good observation point of 
employee's worries about the state of the company. In this space, people open up and say what they will often remain silent in the company space (Kiley and Welch, 2006).

Last but not least, food expresses status. The division of eateries, with different ranks having their own space in the armed forces but also in some work organizations, expresses the status of each group in the organization. If people are what they eat, different food expresses different identities at work. Fine food is reserved for people who think themselves fine, while simple food feeds simple people. As noted by Rosen (1991: 79), "the type of food eaten by the group signifies its image of itself in a particular role”. In egalitarian Japanese organizations, everyone eats the same food in the same places, in a symbolic statement that sends clear messages about the values of the organization (Kono and Clegg 2001). Kets de Vries (2001: 102) notes that bestplace-to-work firms organize a number of events that help to create a sense of community: "Friday evening beer bashes, parties to celebrate company milestones, company picnics". The perks offered by these organizations to their employees, include “great cafeterias with great food” (Kets de Vries, 2001: 102).

\section{FOOD AND SYSTEM DESIGN}

The understanding of food and eating is not possible without the analysis of food and eating habits as a system design that is shaped by the cultural and institutional terrain. If people need food, the understanding of what "food" means is culturally defined and institutionally bound. In this section we discuss these two facets of the organization of food. 
Food provides a window to the observation of technology. The idea of milk as good food is widely shared today, at least in the west - in China it is regarded as a suspicious substance, the source of the peculiar sour smell that the Chinese attribute to westerners. If other countries serve as contrasts, so too do our recent histories: in the past, before pasteurization, milk was a very dangerous product and a source of many diseases such as tuberculosis (Wolf 2004: 331). Therefore, the meaning of "food" cannot be fully apprehended without taking the organizational context in which it is situated into consideration. In the case of cow's milk a dangerous drink was transformed into part of a good diet as a result of the work of social institutions, namely the design of a scientific system that could institute standards and tests for these standards. Societies have failed because they could not give up their food culture, as Diamond (2005) explains in the case of the Norse settlers in Greenland, whose cultural dependence on cows denuded and impoverished their landscape, eventually killing them off, while Inuit migrants flourished because their technologies for food were not pastoral but maritime, premised on hunting for mammals from speedy kayaks with harpoons and other tools. Whole societies have prospered on simple organizational technologies: the invention of freezing, for instance, turned much of New Zealand from a land that mostly supported those indigenous fauna that had survived the waves of immigrants, from the Maori onward, to a lush grassland that supports three and a half million people and sixty million sheep. The rise of New Zealand lamb depended on the technologies of freezing and the organization of mercantile shipping to enable it to reproduce British workers.

Food derives its meaning not only from social, economic, and technical knowledge but also from that which is religious. Food is the major object of religious taboo across all cultures: what you can eat is usually as regulated as whom you can marry. Proper food 
in one context may mean forbidden food in another. The history of food is a history of taboo and of harsh dietary restrictions, as depicted by Allen (2002). Additionally, the social embeddedness of food and its relation with human existence is well captured in the history of food fears and hysterias. Mad cow disease and bird flu are only two recent examples of the historical terror that the interdependence of man, animals and food can create (Ferrières, 2002). Food is not only a basic need for survival but also an institutionalized and organized field across which periodic moral panics play out (Cohen 1972). Food production, of coursed, is a highly industrialized process. Fordism began with observation of the moving line for butchery in the Chicago slaughterhouses; in turn, the techniques of factory farming derive a great deal of their rationale from the organization of people as docile and managed bodies attempted by Taylorism and Fordism. The pig in its pen, like the Taylorized worker, is allowed only optimal - from the point of view of production efficiency - movement. The chicken in its coop in the battery farm pecks at a moving line of food.

Human organization establishes how food, and what food, can be produced. It enact a number of norms that materialize and reproduce the social identity of the group in which it emerges. As discussed by Ferrières (2002), texts normalizing the selling of meat are as old as 1200AD. Between 1200 and 1400, a codex alimentarius gained shape in France and constituted the basis for legislation about food. The emerging texts regulated a number of aspects related to meat consumption, including the right to sell, the conditions of selling, the location of abattoirs, etc. Hence the notion put forth by the idea of la viande politique, political meat. Texts aimed at rationalization were starting to transform food into de-materialized food. Meat was not only food, but politics and a source of identity: the forbidden pork, the sacred cow, the idea that "Meat is Murder", 
as The Smiths' song goes, or the recent discussion around the Baltic herring as the national fish in Estonia, are examples of social-political identities constituted around people's relation to food. As Ruve Schank, an official of the Estonian Agriculture Ministry noted a propos the Baltic herring issue, "Food has a political dimension" (Rhoads, 2007). Food feeds the body and shapes thinking. The cultural-cuminstitutional aspects associated with food are not a mere curiosity. They are crucial for some organizations, including multinationals in the food sector, which have to be sensible to local facets of dietary restrictions when they move abroad: McDonald's has to recognise the limits of selling beefburgers to people for whom the cow is sacred animal. All international organizations have to accept that those bodies they employ will have deeply-held and very specific notions about the nature of food, its production, slaughter and consumption, which they will affront to their peril.

Food is a cultural mirror. In the case of international business meals, one's national basic rules of etiquette may be rendered inadequate and national stereotyping may come to surface. Indeed, food is one of the few areas left where business advice can be pointedly stereotyped ethnically:

The French are almost like Japanese in the sense that they have to get to know the person they are doing business with. (...) Remember that they want to be respected as cultural folk with a proud tradition. You may not be a gastronome yourself, but it is crucial to show a proper appreciation of food and drink (Collins, 1994: 22).

In the same vein, someone doing business in Mexico should know that business meals can last from two to three hours (Alisau, 1997) in the middle of the day, after which you return to work, and that meetings rarely start on time, such that a little delay, (of 20 
minutes or more), is perfectly natural according to national habits. For Americans, this may appear intolerable (Welch, 2000). With respect to table manners, one should also be aware that "Asians are accustomed to making loud noises (slurping, burping, openmouth chewing, and lip-smacking) to signify appreciation of a meal” (Moline, 1998: 68). When hot at the dining table business men will roll their trouser legs up to cool down ${ }^{3}$. In general, the literature on intercultural business relationships and business travel faux pas tells us as much about cultural stereotyping as they do about business relationships.

Food can also serve to analyze the processes of institutionalization. Eating codes and habits emerge through long civilizing processes, with some practices being stabilized as institutional fields, ranked in guides (Karpik, 2000) and preserved in texts and discourses that control consumption and transform it into an intellectual activity (Ferguson, 1998). Norbert Elias (1982) explored the process of institutionalization of culinary regimes, eating habits, and rules of etiquette. The simple matter of table arrangements, cutlery, its correct lay out and use, are revealed as the outcome of a complex social and hierarchical organization slowly spreading from courtly society to the bourgeois home. Rao, Monin and Durand (2003, 2005, Durand, Rao, and Monin 2007) have used French cuisine to study processes of strategic persistence and change.

The emergence of gastronomic schools such as nouvelle cuisine and star chefs, such as Ferran Adrià (Svejenova, Mazza \& Planellas, 2007), also open important potential for organizational studies in several areas, including experiential consumption and the inventive use of resources. Nouvelle cuisine may be a fertile soil in which to study processes of improvisation - and therefore act as a good alternative to the dominant jazz

\footnotetext{
${ }^{3}$ Graham Sewell, personal communication.
} 
metaphor. Durand et al. (2007) point out that chefs consider that classical cuisine emphasizes hierarchy and structure whereas nouvelle cuisine requires autonomy and improvisation. Food may thus help to expose processes that have been obscured in the mainstream organizational literature. Bricolage and improvisation are two possible examples of how the creative use of ingredients may help new flavours be innovated. Bricolage may be equally relevant in Aunt Virginia's kitchen (Moore, 1991) as to HEC MBA students:

under the direction of the campus chef they served an elegant dinner - salad with duck, beef bourguignon, and a dessert of crème anglaise, meringue and caramel - to more than 100 guests. Later, they viewed video recordings of the dinner and discussed their experiences in the kitchen (Alsop, 2006: 32).

Finally, food has appeared in the critical literature as a political resource; for instance, in Rosen’s (1988) study of employee resistance at the bosses’ expense at Christmas.

\section{FOOD PRODUCTION AS A SOURCE OF METAPHORS FOR SYSTEMATIC CRITIQUE}

How food is produced has also been a privileged terrain for the critical and metaphorical analysis of business and society. A salient target for several social groups, including organizational scholars, is the McDonald's corporation. Consider for example the work of David Boje, the self-described “agent provocateur of the postmodern era” (Boje, 2004: 288), who presents this fast-food company as “an imperial force, globalization power, and colonizer of local culture” (Boje, 2004: 290). In other words, McDonald's is evil and Ronald McDonald the "contemporary clown prince”. Another well-known criticism of the contemporary society and lifestyle centred on McDonald's is the so- 
called McDonaldization thesis, or the McDonaldization of society. Fast-food restaurants have become seen as the standard format for the spread of a global nothingness in which, increasingly, what is consumed loses any unsystematic or idiosyncratic local characteristics (Ritzer, 1999; 2002; 2004). The Big Mac (preferably served with Coke, another favourite of the critics), and the McDonald's corporation thus became the symbols of our days in “McDonaldland” or “McWorld”, to use Barber’s (2001) formulation of the aggressive neo-liberal agenda.

A feature of McDonald's and other franchise restaurants is that they expose their clients to carefully-designed and themed environments (Gottdiener, 1998). In these environments, highly standardized and rationalized organizations are able to overstimulate consumers that, elsewhere, may be under-stimulated as workers by precisely the same types of standardized and rationalized work that they do. Organizations use wages and salaries to rent people's time, in jobs that often hardly capture their imaginations even as, they seek loyalty and reliability as Jacques (1996) notes. Wages can be used to grant access to consumption spaces that re-enchant mundane reality through spectacle, such as mega-malls, in every one of which there will be found a McDonald's, and which are themselves often described as McMalls.

The criticism of the McDonaldized society is not limited to the abstract level of alienation, disenchantment and the values that McDonald's represents. In some cases it targets food itself. Super Size Me, the 2004 movie directed by Morgan Spurlock, pointed out the physical damage provoked by the excess of fast and junk food, which is a significant concern in developed countries (Berry, Seiders and Hergenroeder, 2006). For the first time in history, it is the excess rather than lack of food that has become a 
major concern. The organization of demand for food by the major food corporations and fast-food outlet has been so successful that they are killing their market through saturated and trans fats, obesity and high cholesterol.

In response to the movement of food industrialization and life acceleration, some groups develop new identities and subcultures centred on food. The most evident cases are those of vegetarians and vegans (Iacobbo and Iacobbo, 2006), but other examples exist, including Slow Food, a movement established to preserve the richness, tradition, flavour, and life style associated with cooking habits and ingredients not yet tainted by the industrialization of food production and consumption (e.g., Levitt, 1976). Slow Food is dedicated to preserving regional ingredients and styles of cooking; closely related to these ideas is the development of regional Farmers' Markets and the idea that consumers should seek to minimize the food miles that the produce they eat has travelled.

Criticism is not only oriented towards lifestyles but also the systems that produce the food commodities that fuel them. The capitalist system of production has been included in the critical agenda relating food and organization. Mad cow disease resulted from a diminishing regard for safety and respect for both animals and consumers. Feeding ruminants on the scrapings of dead sheep's carcases proved not to be a smart idea. A different mode of functioning would have prevented this disease. ${ }^{4}$

Still in the realm of critique, researchers may wish to explore how the colonizers were "colonized in reverse" through gastronomy. The appreciation in the west of the

\footnotetext{
${ }^{4}$ It has not occurred in isolated continents that never practiced this form of animal husbandry, such as Australia and New Zealand.
} 
gastronomies of the "rest" and its impact on representations of the countries where they originated (e.g. India), is a fertile terrain for the study of post-colonial themes. These may include, for example, the process of transformation of once "ethnic" foods through global franchises, as has happened with Chinese, Japanese and Mexican food but has not happened with Polish, Russian or Kazakhstan cuisine, for instance. It could address the invention of tradition around phenomena such as Balti food in the British West Midlands or how what was, in terms of its providores, Muslim Pakistani or Bangladeshi cuisine, some thing that became associated with Hindi Indians as a generic style of food. Behind the dish there reside complex stories of ethnic tension, communal strife and "ethnic cleansing” such that, at certain historical moments, in cities such as Bradford, which restaurant one chose to eat in was as much a political as a culinary judgement, as Bangladesh fought its war of independence from Pakistan, and India fought with Pakistan in 1971. The pictures of the respective national leaders were displayed in the windows so there could be no doubt whose side the restaurant was on.

Food has been used as metaphor. Human existence, as Christians know it, is supposed to have started with an apple in the Garden of Eden. The idea of food as sin and the etymology of “organization” have a fleshy nature themselves. Eating served to metaphorically distinguish cultures. Gannon's (2004) work illustrates this possibility. In his metaphorical exploration of 28 national cultures, the author included the Danish Christmas luncheon, the Turkish coffee-house, the French wine, and the Korean kimchi as food-related practices that describe distinct cultures.

Organizations are like people; as they get older and more successful, they put on fat (Reis and Peña, 2001). Overweight organizations are regarded as bad and unsuccessful, 
thus requiring an intervention of some kind. The remedy appears to be similar to the one prescribed for individuals: dieting (downsizing), hiring a personal trainer (hiring consultants to do the dirty job of firing people), and do plenty of exercise in the gym (structural changes, removal of managerial layers). The ultimate goal for individuals and organizations alike is to achieve that seductive, slim and beautiful body (make the organization more flexible and more attractive to investors). And the risks are not dissimilar either: Taken too far or too quickly, a sliming programme can become a health hazard. Anorexic firms may experience serious problems. But food may also have other meanings in the field of organizations. Among these, is the search for the best organization.

The search for "best organizations" echoes stories about the mythical Land of Cockaigne (Cunha, 2004). Cockaigne is an imaginary country of unknown location that gave rise, in the Middle Ages, to stories which circulated throughout Europe. Thousands of Cockaigne texts appeared in spontaneous versions that introduced many variations of existing versions. Some of these texts survive until the present day. Based on Pleij (2001) two aspects of this unique place should be noted: the material excess that represents the opposite of scarcity in the real world and that, in many respects, contradicts norms of behaviour, and the moral messages that could be extracted from the legend. Cockaigne was a country tucked away somewhere in a remote corner of the world, where ideal living conditions prevailed:

\footnotetext{
Work was forbidden, for one thing, and food and drink appeared spontaneously in the form of grilled fish, roast geese, and rivers of wine. One had but to open one's mouth, and all delicacies practically jumped in. One could even reside in meat, fish, game, fowl, or pastry, for another feature of Cockaigne was its edible architecture. The weather was stable and mild - it was
} 
always spring - and there was the added bonus of a whole range of amenities: communal possessions, lots of holidays, no arguing or animosity, free sex with ever-willing partners, a fountain of youth, beautiful clothes for everyone, and the possibility of earning money while one slept (Pleij, 2001: 3)

The central element in descriptions of Cockaigne was food. Food was everywhere, on the table but also walking down the street or in the architecture of edible edifices. This obsession with food was caused by the threat of the lack of it. Recollections, rumours and images of great famines circulated throughout Europe and were a cause of considerable anxiety. Being poor and hungry was a normal condition of existence for many landless labourers and not a few with access to land as well. As a consequence, dream worlds were imagined, animated by permanent banquets. To justify these, Cockaigne rapidly acquired distinguishing agrarian attributes, such as the succession of superabundant harvests.

Cockaigne can be viewed as an alimentary paradise, reflected in the name of the place, which may have several origins, all of them associated with food. One possible explanation lies in the French or Provençal words having to do with cooking and a type of honey cake called "cocanha”. Another possibility is the contraction of the suffix “agne”, used in French to indicate a country (such as in "Allemagne” or "Espagne”) with “coc”, or rooster. In this case, Cockaigne could be understood as meaning “The Land of The Rooster”, once again, reminding us of the essence of the place.

There are religious connections that are worth noting. A rooster is named as the guardian of the Muslim paradise, once again suggesting subtle associations between the spiritual and the material, the sacred and the profane. Examples of the divine 
dispensation of food are also offered in the Bible, for example in the form of manna falling from Heaven, or the miracle of the loaves and the fishes. These examples of divine interventions have themselves two complementary readings: humankind was not meant to suffer from hunger, but had only itself to blame for such a terrible deprivation.

Contemporary, temporary and small-scale organizational equivalents of this land of plenty can be found in the top quality restaurant ("If there exists a Land of Plenty on earth, it would be one of these outstanding French restaurants”, Balazs [2002: 257] wrote), in the Chinese banquet, in the food offered "whenever you want it" in some “best workplaces”, in gourmet canteens (Rigby, 2007) and in the high tech firms that hire chefs to retain employees - as previously discussed. A land where food was abundant and work forbidden is in sharp contrast with the harsh realities of everyday life. The pastoral metaphor of the leader as the good shepherd that conducts his/her people to green pastures is a recurrent image in discussions of leadership from biblical times to the present. However, managers may also be viewed according to the Kronos metaphor of the Greek god who swallowed his children. Kronos may represent managers’ desire for power and domination, and portray management as consuming or sucking dry the other in an excess of 'organizational gothic' (Garrick and Clegg 2000; Pelzer and Pelzer, 1996). As in the Greek mythology, critics of today’s capitalistic society still await the powerful Zeus to put an end to this autofagic managerial temptation (Kostera, 2006) or, if they are feminists, they might dream of the 'maternal organization’ (Hopfl and Kostera, 2002) as a ‘feminist bureaucracy’ (Fergusson 1984) something suckling, warm and nurturing. 
The escapism of Cockaigne was to be replaced by images of work where the worker fed the managerial machine. The voracity of organization was a theme for writers and cinema directors alike. Emile Zola’s (1885) Germinal, for example, describes a mine that swallows the miners. Upton Sinclair's (1906) The Jungle is set in a slaughterhouse where the employees end up as food, as a part of pure Dunham's beef lard. In Fritz Lang's (1927) Metropolis, the low class exists in the underworld to "feed" the life styles of those living above. More recently, the Warchowski’s (1999) Matrix presents human bodies as sources of energy for the Matrix. All these works of art resonate with the image of the organization and of capitalists as vampires, a metaphor that Karl Marx (1887) already used and which is still recurrent today. In addition to Garrick and Clegg's use of the metaphor, Parker's (2005) discussion of organizational gothic suggest that the worker feeding the system is still a powerful and deeply ingrained image.

Discussing the different ways in which organizations deal with diversity, Herriot and Pemberton (1995) suggested three sorts of culinary response: (1) the vindaloo model, “whereby everything that's put into the dish ends up tasting the same, however different it was to start with” (p. 8), meaning assimilating diversity and homogenizing it, or else rejecting it and sending it back; (2) the nouvelle cuisine approach, "in which we put a very delicate decoration to the side of the plate so as not to damage it, not being quite sure whether we should be eating it or not” (pp. 8-9). It involves taking categories of people more likely to be disadvantaged in society, such as women and minorities, and define affirmative action plans and enforce legislation to protect them; and (3) the traditional English Sunday lunch" , “wherein roast beef, Yorkshire pudding, roast

\footnotetext{
${ }^{5}$ The tradition has slimmed down over the years. If one consults one of the best-selling English cookbooks , Mrs Beeton's Book of Household Management (accessible at: http://www.mrsbeeton.com/,
} 
potatoes, gravy, and mustard are all indispensable to the success of the meal” (p.9). In this case, the more ingredients there are the richer the culinary experience is taken to be. Each ingredient will be valued for what it adds to the meal. The metaphor is that managing and valuing such tasteful diversity will reinforce the organization’s competitive advantage.

Table 2 provides a contrast of the four perspectives discussed in this section and of their consequences.

Table 2 about here

\section{FINAL COMMENTS}

Despite the explicit lack of scholarly attention to food at work, its importance as a total social phenomenon guarantees a subtle presence in the organizational literature, often in the context of other social phenomena and institution. The absence of an explicit research agenda on food and organizations is unfortunate because the production and consumption of food are to a great extent influenced by the activity of businesses and organizations.

first published in 1861 as The Book of Household Management Comprising information for the Mistress, Housekeeper, Cook, Kitchen-Maid, Butler, Footman, Coachman, Valet, Upper and Under House-Maids, Lady's-Maid, Maid-of-all-Work, Laundry-Maid, Nurse and Nurse-Maid, Monthly Wet and Sick Nurses, etc. etc. - also Sanitary, Medical, and Legal Memoranda: with a History of the Origin, Properties, and Uses of all Things Connected with Home Life and Comfort, one will find that both the number of courses and variety of foodstuffs has slimmed considerably from what today might be regarded as Victorian excess, not to mention titles. 
With this paper we contribute to the inclusion of food in the research agenda on management and organizations (Table 3 advances a sample of potential research topics). We consider four approaches to study the relationship between food and organization, each providing a different window on the functioning of organizations. The four cases also suggest a number of possible lines of inquiry about organizations. We discuss them below:

- Food as need. Despite the cognitive revolution of the 1970s and the emotional intelligence turn of the 1990s, the biological nature of organizations tends to be discounted from the theories of organization. The presence of food in organizational analysis may facilitate the development of more realistic theories. Food is a daily presence in the life of people and therefore the structuring of meals helps to understand the structuring of the organization.

- Food as social interaction. Food provides opportunities for interaction. The way organizations arrange the space for the satisfaction of alimentary needs, expresses the formal distinctions of status and prestige and influences the informal organization and the flows of information. People may use food to create spaces of liminality.

- Food as culture and institution. Food provides a rich field for analyzing the emergence of cultures and institutions. Different organizations develop different eating habits; different societies developed different alimentary and gastronomic institutions. As suggested by the studies of Elias, and Rao and his colleagues, these processes may constitute potent sources of information about organizational processes.

- Food as critique and metaphor. The emergence of dietary habits and regimes is a social process that has stimulated some successful metaphors and angles of 
criticism. The understanding of the organizational society would then be incomplete without consideration of critique of the prevailing food regimes.

We discussed the relationship between food and organization, and suggested that food is anything but banal. The role of food belongs to the everyday stuff of organizational life. The banality often attached to food as something taken-for-granted in the modern age is apparent but not real: technologies had to be invented and developed to allow the trade of precious spices and later, frozen carcases, transforming colonial economies and societies. Religious identities attach great value to eating habits, and major organizational - as well as familial - celebrations often happen around the table.

Table 3 about here

In conclusion, we can understand organizations by better knowing how they relate to food. Food is a structuring dimension of cultures and organizations. It expresses changing lifestyles (e.g., from traditional home-cooked food to fast/microwave food) and can be used to organize resistance (e.g., the Slow Food movement). It is celebratory and marks the existence of organizations. The organized world and its challenges can be approached through the study of food. Organized technological evolution made the impossible possible (e.g. growing bananas in geo-thermally heated greenhouses in Iceland or tomatoes in space). It raises new challenges and concerns, such as in the genetic engineering of foodstuffs (Herring, 2006), attitudes to which, when comparing Europe with the US, provide a major fault-line that US agri-food corporations are 
finding hard to cross. Food is irrevocably tied up with the way its production and consumption is organized and the ways in which its associated cultures shape the practices of organizations in general. 


\section{REFERENCES}

Adler, P.S. Time-and-motion regained. Harvard Business Review, 1993, 71(1), 97-108.

Allen, S.L. In the Devil's garden: A sinful history of forbidden food. Edinburgh: Canongate, 2002.

Alisau, P. Tips for doing business in Mexico. Successful Meetings, 1997, 46(11), 188.

Alsop, R.. More M.B.A. schools find lessons in play. Wall Street Journal, September 12, 2006, 32.

Anderson, P. The transition from feudalism to capitalism. London: New Left Books, 1974.

Balazs, K. Take one entrepreneur: The recipe for success of France’s great chefs. European Management Journal, 2002, 20(3), 247-259.

Barber, B.R. Jihad vs McWorld: Terrorism challenge to democracy. New York: Ballatine Books, 2001.

Barrett, A. Pfizer’s funk. Business Week, February 28, 2005, 50-58.

Beer, S. Brain of the firm (2nd ed.). New York: Wiley, 1981.

Berry, L.L. Seiders, K and Hergenroeder, A.C. Regaining the health of a nation: What business can do about obesity. Organizational Dynamics, 35, 2006, 341-356.

Boje, D.M. Inside the Rabelaisian sileni box. Management Communication Quarterly, 2004, 18, 288-295.

Cabral-Cardoso, C. and Cunha, M.P. The business lunch: Toward a research agenda. Leadership and Organization Development Journal, 24, 2003, 371-379.

Clegg, S.R. and Kornberger, M. (Eds) Space, Organizations, and Management Theory, Oslo and Copenhagen: Liber/CBS Press, 2006. 
Clegg, S.R., Courpasson, D. and Philips, N. Power and organizations. London: Sage, 2006.

Cohen, S. Folk devils and moral panics. London: Routledge, 1972.

Cohen, S. and Taylor, L. Escape attempts: the theory and practice of resistance to everyday life. London: Allen Lane, 1976.

Collins, R. Le style français. Resident Abroad, July1994, 20-25.

Conlin, M. Square feet. Oh how square! Business Week, July 3, 2006, 100-101.

Conquest, R. The Harvest of Sorrow: Soviet Collectivization and the Terror-Famine. Oxford: Oxford University Press, 1986.

Cunha, M.P. In search of organizational Cockaigne: Identifying the pillars of the ideal organization. Journal of Management, Spirituality and Religion, 2004, 1(1), 7792.

Cunha, M.P. and Cabral-Cardoso, C. Shades of gray: A liminal interpretation of organizational legality-illegality. International Public Management Journal, 2006, 8(3).

Diamond, J. Collapse: How Societies Choose to Fail or Succeed. New York: Viking, 2005.

Durand, R., Rao, H. and Monin, P. Code and conduct in French cuisine: Impact of code changes on external evaluations. Strategic Management Journal, 2007, 28, 455472.

Eisenhardt, K.M. Building theories from case study research. Academy of Management Review, 1989, 14, 532-550.

Elias, N. The civilizing process. New York: Pantheon, 1982.

Fairbank, J. K. China: A new history. Cambridge, MA: Harvard University Press, 1992. 
Fayard, A.L. and Weeks, J. Copiers and water coolers: The affordances of informal interaction. Organization Studies, 2007, 28, 605-634.

Fergusson, K. (1984) The feminist case against bureaucracy, Philadelphia: Temple University Press.

Ferguson, P.P. A cultural field in the making: Gastronomy in 19-th century France. American Journal of Sociology,1998, 104, 597-641.

Ferrières, M. Histoire des peurs alimentaires. Paris: Seuil, 2002.

Filbeck, G. and Preece, D. Fortune’s best 100 companies to work for in America: Do they work for shareholders? Journal of Business Finance and Accounting, 2003, 30, 771-797.

Financial Times. FT Best Workplaces. Special report, May 18, 2006.

Fineman, S. Emotion and organizing. In S.R. Clegg, C. Hardy and W.R. Nord (Eds) Handbook of organization studies. London: Sage, 1996, pp.543-564

Gannon, M. Understanding global cultures, 3rd ed.. Thousand Oaks: Sage, 2004.

Garrick, J. and Clegg, S. R. Organizational gothic: Transfusing vitality and transforming the corporate body through work-based learning. In C. Symes and J. McIntyre (Eds) Working knowledge: The new vocationalism and higher education. Buckingham: The Society for Research into Higher Education and Open University Press, 2000, pp153 -171.

Goffman, E. The presentation of self in everyday life. Harmondsworth: Penguin, 1956.

Gottdiener, M. Themed environments of everyday life. Restaurants and malls. In A.A. Berger (Ed.), The postmodern presence: Readings on postmodernism in American culture and society. Walnut Creek, CA: Altamira, 1998, pp.74-87.

Guégen, N. and Petr, C. Odors and consumer behaviour in a restaurant. Hospitality Management, 2006, 25, 33-339. 
Hammer, M. and Champy, J. Reengineering The Corporation: A Manifesto for Business Revolution. New York: Harper Business, 1993.

Hannan, M.T. and Freeman, J. Organizational ecology. Boston, MA: Harvard University Press, 1989.

Harquail, C. V. (2006). Employees as animate artifacts: Wearing the brand. In A. Rafaeli and M. G. Pratt (Eds.), Artifacts and organizations: Beyond mere symbolism (pp. 161-180). Mahwah, NJ: Lawrence Erlbaum Associates.

Hassard, J. Holliday, R. and Willmott, H. (Eds.) Body and organization. London: Sage, 2000.

Hearn, J., Sheppard, D.L., Tancred-Sheriff, P. and Burrell, G. The sexuality of organization. London: Sage, 1989.

Herring, M.Y. Genetic engineering. New York: Praeger, 2006.

Herriot, P. and Pemberton, C. Competitive advantage through people: Organizational learning from difference. London: Sage, 1995.

Hofbauer, J. Bodies in a landscape: On office design and organization. In J. Hassard, R. Holliday and H. Willmott (Eds.), Body and organization. London: Sage, 2000, pp.166-191.

Hopfl, H. and Kostera, M. (Eds.) Interpreting the maternal organization. London: Routledge, 2002.

Iacobbo, K. and Iacobbo, M. Vegetarians and vegans in America today. New York: Praeger, 2006.

Jacques, R. Manufacturing the employee. Management knowledge from the 19th to 21st century. London: Sage, 1996.

Karpik, L. Le guide rouge Michelin. Sociologie du Travail, 2000, 42, 369-389. 
Katz, D. and Kahn, R.L. The social psychology of organizations (2nd ed.). New York: Wiley, 1978.

Kets de Vries, M.F.R. Creating authentizotic organizations: Well-functioning individuals in vibrant companies. Human Relations, 2001, 54, 101-111.

Kiley, D. and Welch, D. Trickle-down despair at Ford. BusinessWeek, August 21, 2006, 33.

Kono, T. and Clegg, S. R. Trends in Japanese Management, London: Palgrave, 2001.

Kostera, M. After Kronos: Management in search of new archetypes. Paper present at the 3rd Conference on the Art of Management and Organization, Krakow, September, 2006.

Lang, F. (Director) Metropolis, Berlin: Universum Film A.G. (UFA), 1927.

Levitt, T. The industrialization of service. Harvard Business Review, SeptemberOctober, 1976, 63-72.

Linstead, S. Dangerous fluids and the organization-without-organs. In J. Hassard, R. Holliday and H. Willmott (Eds.), Body and organization. London: Sage, 2000, pp.31-51.

Marx, K. Capital. Harmondsworth: Penguin, 1887/1976.

McNamee, G. Moveable feasts: The history, science, and lore of food. New York: Praeger, 2006.

Moline, J. Travel faux pas. Global Finance, 1998, 12 (4), 68.

Moore, L.F. Inside aunt Virginia’s kitchen. In P.J. Frost, L.F. Moore, M.R. Louis, C.C. Lundberg and J. Martin (Eds), Reframing organizational culture. Newbury Park, CA: Sage, 1991, pp.366-372.

Morgan, G. Images of organization. Beverly Hills: Sage, 1986. 
Morgan, G., Frost, P.J. and Pondy, L.R. Organizational symbolism. In L.R. Pondy, P.J. Frost, G. Morgan and T.C. Dandrige (Eds), Organizational symbolism, Greenwich, CT, 1983, pp.3-35.

Parker, M. Organisational gothic. Culture and Organization, 2005, 11, 153-166.

Pelzer, J. and Pelzer, L. Coffee houses of Augustan London. History Today, 1982, October, 40-47.

Pelzer, P. and Pelzer, M. The gothic experience: Gothic music as an example for role and function of contemporary culture. Paper presented at the 14th international SCOS Conference, Los Angeles, 1996.

Pitsis, T., Clegg, S. R, Marosszeky, M. and Rura-Polley, T. Constructing the olympic dream: A future perfect strategy of project management. Organization Science, 2003, 14, 574-590.

Pleij, M. Dreaming of Cockaigne. Medieval fantasies of the perfect life. New York: Columbia University Press, 2001.

Rafaeli, A., Dutton, J., Harquail, C.V. and Mackie-Lewis, S. Navigating by attire: The use of dress by female administrative employees. Academy of Management Journal, 1997, 40, 9-45.

Rafaeli, A. and Pratt, M. (Eds) Artifacts and organizations: Beyond mere symbolism. Mahwah, NJ: Lawrence Earlbaum, 2006.

Rao, H., Monin, P. and Durand, R. Institutional change in Toque Ville: Nouvelle cuisine as an identity movement in French gastronomy. American Journal of Sociology, 2003, 108, 795-843.

Rao, H., Monin, P. and Durand, R. Border crossing: Bricolage and the erosion of categorical boundaries in French gastronomy. American Sociological Review, 2005, 70, 968-991. 
Reis, D. and Peña, L. Reengineering the motivation to work. Management Decision, 2001, 39, 666-675.

Rhoads, C. Russia, beware: Estonia chooses Baltic herring as its national fish. Wall Street Journal, June 14, 2007, 36.

Rigby, R. Gourmet canteens that give workers food for thought. Financial Times, July 30, 2007, 10.

Ritzer, G. Enchanting a disenchanted world: Revolutionizing the means of consumption. Thousand Oaks: Pine Forge Press, 1999.

Ritzer, G. The McDonaldization of society (2nd ed.). Thousand Oaks, CA: Pine Forge Press, 2002.

Ritzer, G. The globalization of nothing. Thousand Oaks, CA: Pine Forge, 2004.

Rosen, M. You asked for it: Christmas at the bosses' expense. Journal of Management Studies, 1988, 25, 463-480.

Rosen, M. Breakfast at Spiro’s: Dramaturgy and dominance. In P.J. Frost, L.F. Moore, M.R. Louis, C.C. Lundberg and J. Martin (Eds.), Reframing organizational culture. Newbury Park, CA: Sage, 1991, pp.77-89.

Schein, V.E., Mueller, R., Lituchy, T. and Liu, J. Think manager - think male: A global phenomenon? Journal of Organizational Behavior, 1996, 17, 33-41.

Salvendy, J. Handbook of human factors and ergonomics. New York: Wiley, 1997.

Shilling, C. The body and social theory. London: Sage, 1993.

Sinclair, A. Body possibilities in leadership. Leadership, 2006, 1, 387-406.

Sinclair, U. The jungle. New York: Doubleday, 1906.

Svejenova, S., Mazza \& Planellas, M. cooking up change in haute cuisine: Ferran Adrià as an institutional entrepreneur. Journal of Organizational Behavior, 2007, $28,639-561$. 
Taylor, F.W. The principles of scientific management. New York: W.W. Norton, 1911.

Warchowski, A. and Warchowski, LK. (Directors) The Matrix, Los Angeles: Warner Bros. Pictures, 1999.

Wallerstein, I. The Modern World System: Capitalist Agriculture and the Origins of the European World Economy in the Sixteenth Century. New York: Academic Press, 1974.

Welch, S.J. Coming to America. Successful Meetings, 2000, 49(6), 39-41.

Whitley, R., Thomas, A. and Marceau,J. Masters of business? Business schools and business graduates in Britain and France. London: Tavistock, 1981.

Wolf, M. Why globalization works. New Haven, CT: Yale University Press, 2004.

Zola, E. Germinal. Paris: Gallimard, 1885. 
Table 1

Food and organization: A typology

\begin{tabular}{|c|c|c|c|}
\hline \multirow{4}{*}{ Consuming food } & \multicolumn{2}{|c|}{ The materiality of food } & \multirow{4}{*}{ Producing food } \\
\hline & Biological necessity & System design & \\
\hline & Social reproduction & Systematic critique & \\
\hline & \multicolumn{2}{|c|}{ Food's role in social construction } & \\
\hline
\end{tabular}


Table 2

Food and organization: Contrasting approaches

\begin{tabular}{|c|c|c|c|c|}
\hline & $\begin{array}{l}\text { Biological } \\
\text { necessity }\end{array}$ & Social reproduction & System design & Systematic critique \\
\hline Explanation & $\begin{array}{l}\text { Food as a provider } \\
\text { of need } \\
\text { satisfaction. }\end{array}$ & $\begin{array}{l}\text { Food as facilitator } \\
\text { of interaction and } \\
\text { expression of status }\end{array}$ & $\begin{array}{l}\text { Food and eating as } \\
\text { regulated patterns } \\
\text { of activity. }\end{array}$ & $\begin{array}{l}\text { Food as symbol } \\
\text { and reflection of } \\
\text { contemporary } \\
\text { societies. }\end{array}$ \\
\hline Purpose & $\begin{array}{l}\text { Fulfilling a } \\
\text { physiological need. }\end{array}$ & $\begin{array}{l}\text { Fulfilling a social } \\
\text { need. }\end{array}$ & $\begin{array}{l}\text { Food as habit and } \\
\text { rule. }\end{array}$ & $\begin{array}{l}\text { Exposing how } \\
\text { consumerist culture } \\
\text { distorts health and } \\
\text { life }\end{array}$ \\
\hline Illustrations & $\begin{array}{ll}\text { - } & \text { Organization } \\
\text { as a bodily } \\
\text { reality. } \\
\text { - } \text { The culinary } \\
\text { experience. } \\
\text { - } \quad \text { Eating as } \\
\text { sensual } \\
\text { pleasure. } \\
\text { Food as a } \\
\text { source of } \\
\text { identity (e.g., } \\
\text { vegetarianism) }\end{array}$ & $\begin{array}{ll}\text { - } & \text { Meals as social } \\
\text { events } & \text { Meals as } \\
\text { opportunities } \\
\text { for liminality } \\
\text { Eating spaces } \\
\text { and food as } \\
\text { expressions of } \\
\text { status and } \\
\text { organizational } \\
\text { order }\end{array}$ & $\begin{array}{ll}\text { - } & \text { Food as a } \\
\text { highly } \\
\text { regulated field. } \\
\text { - } \quad \text { The business } \\
\text { lunch. } \\
\text { - Table } \\
\text { manners. } \\
\text { The brown bag } \\
\text { - } \quad \text { Eaminar. } \\
\text { Eating habits } \\
\text { as institutions. }\end{array}$ & 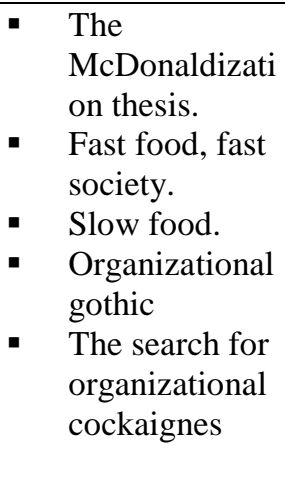 \\
\hline $\begin{array}{l}\text { Representative } \\
\text { researchers }\end{array}$ & $\begin{array}{l}\text { Maslow, Kets de } \\
\text { Vries }\end{array}$ & $\begin{array}{l}\text { Rosen, Pelzer and } \\
\text { Pelzer }\end{array}$ & $\begin{array}{l}\text { Elias; Rao, Durand } \\
\text { and Monin }\end{array}$ & $\begin{array}{l}\text { Boje, Ritzer, Hopfl } \\
\text { Kostera }\end{array}$ \\
\hline
\end{tabular}


Table 3

Possible research questions on work, food and organization

\begin{tabular}{|c|c|}
\hline $\begin{array}{l}\text { Biological } \\
\text { necessity }\end{array}$ & $\begin{array}{l}\text { - What is the real impact of canteen food quality on employee appreciation of } \\
\text { - } \quad \text { Is food only a hygienic factor? } \\
\text { - } \quad \text { Is there anything specific about the motivation of chefs? } \\
\text { - What are the psychological benefits of the introduction of healthy diets in } \\
\text { - } \quad \text { How does obesity impact organizational outcomes? } \\
\text { - How do working lifestyles impact the consumption of food? }\end{array}$ \\
\hline Social reproduction & $\begin{array}{l}\text { - What really happens at business meals? } \\
\text { - What is the role of meals in the construction of esprit de corps? } \\
\text { - When is a liminal space created in the process of business dining? } \\
\text { - What happens after sharing the liminal space? } \\
\text { - What is the relationship between normalization of ethical misconduct, the } \\
\text { - What is the influence of corporate canteens on organizational climate? }\end{array}$ \\
\hline \begin{tabular}{|l|} 
System design \\
\end{tabular} & $\begin{array}{l}\text { - What are the similarities and differences between business lunches and the role } \\
\text { that they play in different countries? } \\
\text { - What are the similarities and differences between business lunches and } \\
\text { business dinners? } \\
\text { - What does the comparative analysis of the system design of food production } \\
\text { and consumption systems say about the emergence of the organizational } \\
\text { society in different social formations? }\end{array}$ \\
\hline Systematic critique & $\begin{array}{l}\text { - What is the impact of shareholder orientation and the profit motive on the } \\
\text { - } \quad \text { Why has McDonald's emerged as one of the preferred images of corporate } \\
\text { global evil? } \\
\text { - How have specific versions of ethnic food become global? How have local } \\
\text { entrepreneurs managed to create a global appeal for the food? Which foods } \\
\text { travel; which foods don't? } \\
\text { - What is the impact of food in the representation of the "rest" in the west? } \\
\text { - How do food scares emerge? } \\
\text { - How do organizations recreate the experience of plenty? } \\
\text { - What can organization in general learn from different genres of restaurant - in } \\
\text { addition to McModels? }\end{array}$ \\
\hline
\end{tabular}

